\title{
BIG SHIPS IN HISTORY.
}

By R. C. ANDERSon.

THERE are many references to be found here and there to ships of a remarkable size for their epoch. As a rule definite figures are somewhat scarce, and even when they are given it is often difficult to make comparisons, because of the variations and uncertainties in the methods of measurement. Still it is possible to piece together a certain amount of information, and this I have tried to do in the following article.

The first mention of actual dimensions that I have found, dates from the beginning of the sixteenth century; before this I know of nothing more definite than that various ships were of $I, 000$ tons, obviously a round number merely, though early tonnage measurement was very probably not quite so unscientific as is generally supposed. The English Regent, for instance, a ship of $I 489$, is said to have been of $I, 000$ tons, and was in all probability the biggest ship of her time.

The first figures available, those for the Scottish ship Great Michael, of 1506 , are somewhat startling. She is said to have been $240 \mathrm{ft}$. long over all, and $36 \mathrm{ft}$. broad withinboard, while her sides were " ten foot thick in the wall and boards, on every side so slack, and so thick that no cannon could go through her." She was lost at sea in I5I2. Probably she was the cause of the building of the Henri Grace a Dieu, launched in 1514, and described as of 1,000 or 1,500 tons. No actual measurements are to be found for this ship or for her French successor, the Grand Francais, of 1,500 or 2,000 tons. This latter ship had, however, five masts with four tops on the mainmast, the uppermost so high that a man in it would appear from the deck to be no bigger than a fowl, while her length was such that a ball could hardly be thrown from one end to the other. Like the Great Michael, she was unlucky; in fact, she never reached open water and was wrecked in harbour in 1533 .

A year before this there had been launched a very large Swedish ship, the Stora Krafvel (Great Caravel). For her we have exact authentic dimensions. She was I79 ft. long over all, 
I57.5 ft. exclusive of the beak, and $134 \mathrm{ft}$. on the under side of the keel, the " tread " ; her beam was $4 \mathrm{I} \mathrm{ft}$., her draught of water II ft., and her total depth at the stern $39 \mathrm{ft}$. Her mainmast was $130 \mathrm{ft}$. long and $18.5 \mathrm{ft}$. thick at the bottom, with a mainyard of I05 ft. Her sides were $6 \mathrm{ft}$. thick ; not quite so thick proportionately as those of the Great Michael, but still pretty stout. Another Swedish ship, the Mars of 1563 , burnt in action in the following year, was perhaps a little bigger. Chapman, the great Swedish naval architect, reckoned that she must have been $\mathrm{I} 6 \mathrm{oft}$ from stem to stern, without the beak, and $4 \mathrm{I} \mathrm{ft}$. wide. She was, however, undoubtedly surpassed by the Adler of Lübeck, built in I566, for this ship was $220^{\circ} 5 \mathrm{ft}$. long overall and $122 \mathrm{ft}$. on the keel (presumably the measured keel, not the tread), while her extreme beam was $49^{\circ} \mathrm{I} \mathrm{ft}$. She must have drawn much more water than the Stora Krafvel, since her depth at the stern was $7 \mathrm{rft}$. Her mainmast was shorter than that ship's, II8 ft., but its yard was longer, II6 ft.

English ships at this time were comparatively small, especially in beam; the broadest Elizabethan ship, the Triumph, measured only $40 \mathrm{ft}$. in beam, while the greatest keel-length was the IIo ft. of the White Bear and Merhonour. Under these circumstances, the Portuguese Madre de Deos, captured in I592, appeared parti cularly remarkable. In length she was about the same as the biggest English ship, being Ioo ft. on the keel and $165 \mathrm{ft}$. over all, but her beam of $46.8 \mathrm{ft}$. was a great increase on anything previously seen in this country. It is uncertain how she compared with other Portuguese and Spanish ships, the " great San Philip," for example, but probably she was nearly if not quite as large as the largest of them.

The Madre de Deos was never used by her captors, but it is perhaps allowable to trace her influence in the great increase of dimensions that took place in English shipbuilding in I6ro, when the Prince Royal was launched. This ship was $43{ }^{\circ} 5 \mathrm{ft}$. in beam, II $5 \mathrm{ft}$. on the keel, and probably about 2 ro $\mathrm{ft}$. over all. She was soon surpassed by the Sovereign of the Seas of $1637,232 \mathrm{ft}$. long over all, I28 ft. on the keel, $48 \mathrm{ft}$. in beam and $76 \mathrm{ft}$. from her keel to the top of her stern-lantern; roughly of the same size as the Adler of I566. The Sovereign seems to have marked the greatest extension of the beak; subsequent ships exceeded her in keel or gun-deck length by more and more, but her over-all length was not beaten until a century later.

A French ship, the Couronne, launched a year after the Sovereign, was almost exactly the same size, though carrying only 
72 guns as compared with I02; she was some $2 \mathrm{ft}$. shorter than the Sovereign, but a few inches wider. For some years there was a pause in the building of very big ships in either country. A Swedish ship, the Krona, completed in 1672 , and lost in action in $I 676$, was remarkable for her length, being $I 74 \mathrm{ft}$. without the beak, but her small beam of $42^{\circ} 3 \mathrm{ft}$. left her a long way short of the Sovereign or the Couronne in tonnage. The French Soleil Royal of 1675 was the first ship to surpass the Sovereign to any extent; she was I75 ft. from stem-post to stern-post, I5I ft. on the tread, and $46.8 \mathrm{ft}$. in beam inside the planking. The Royal Sovereign, at her rebuilding in 1684 , brought back the record to England with a gun-deck length of $174^{\circ} 5 \mathrm{ft}$., a tonnage keel length, of $\mathrm{r}_{4} \mathrm{I} \cdot 6 \mathrm{ft}$., and an extreme beam of $50 \mathrm{ft}$., but in $\mathrm{r} 692$ France went well ahead again with the Royal Louis of $187 \mathrm{ft}$. post to post, $158 \mathrm{ft}$. tread, and 5 I.I ft. beam.

For a few years Denmark was the possessor of the largest ship afloat, the Fridericus IV., launched in 1699 with a length from stem-post to stern-post of $190^{\circ} \mathrm{ft}^{\mathrm{ft}}$, and a beam of $5 \mathrm{I}^{\circ} 3 \mathrm{ft}$. Probably this was soon beaten by the French, who kept their position almost unassailed for a century or more. One of their ships, another Royal Louis, reached a length, post to post, of $202 \mathrm{ft}$., and a beam of $54.3 \mathrm{ft}$., while others were nearly as big. This particular ship was laid down at Brest in $x 740$, and burnt in I742, while still on the stocks; another vessel was, however, built on the same plans at Toulon, and was in existence up to the time of the War of American Independence.

Before this the record had passed to Spain, at least in length, the Santisima Trinidad of 1769 being $204 \mathrm{ft}$. long, and $53.8 \mathrm{ft}$. wide. Both ships were, of course, beaten by the famous Commerce de Marseille, launched in 1790 , and captured at the fall of Toulon in I792. This ship was $2 \mathrm{II}^{\prime} 5 \mathrm{ft}$. long, post to post, $208.6 \mathrm{ft}$. on the gun deck, $186^{\circ} 5$ on the tread, and $I 7 I^{\prime} 9 \mathrm{ft}$. in tonnage keel, with a breadth of $54^{\circ} 8 \mathrm{ft}$. extreme or $54 \mathrm{ft}$. moulded; her depth in hold was $25 \mathrm{ft}$., and her maximum draught $26.5 \mathrm{ft}$. I have not found any ship that beat her in length, but the Montebello, launched in 1812 , and rebuilt in 1821 , went well beyond her in beam with an extreme measurement of $57.3 \mathrm{ft}$. on a gun deck length of $207.5 \mathrm{ft}$. The English Queen of 1839 had a beam of $60 \mathrm{ft}$., but was only $204^{\circ} \mathrm{ft}$. on the gun deck, and $166^{\circ} 4 \mathrm{ft}$. in tonnage keel-length. The proposed I7o gun four-decker Duke of Kent, which was to have had a gun-deck length of $22 \mathrm{I}^{\circ} 5 \mathrm{ft}$., and a beam of $64 \mathrm{ft}$. would have quite eclipsed all previous efforts, but unfortunately, or perhaps fortunately, was never built and remained merely a proposition. 